\title{
Chemical and Biological Composition of Suspended Particles and Aggregates in the Baltic Sea in Summer (1999)
}

\author{
A. Engel ${ }^{a, b}$, M. Meyerhöfer ${ }^{a}$ and K. von Bröckel ${ }^{a}$ \\ ${ }^{a}$ Institute for Marine Research, University of Kiel, D-24109 Kiel, Germany
}

Received 17 April 2001 and accepted in revised form 20 August 2001

\begin{abstract}
Suspended particles and particle aggregates, which formed from concentrated field samples on the roller table, were characterized biologically and chemically along a transect through the Baltic Sea in summer 1999. Phytoplankton composition in field samples was dominated by cyanobacteria, including the filamentous diazotrophic cyanobacteria Aphanizomenon 'baltica', Nodularia spumigena and Anabaena spp. These species formed aggregates together with diatoms, mainly Skeletonema costatum and Chaetoceros spp. and with dinoflagellates, mainly with Dinophysis norvegica. Compared to the Redfield ratio, concentration ratios of particulate organic carbon, nitrogen and phosphorus, [POC]:[PON]:[POP], indicated an enrichment of carbon, especially in aggregates. However, regression analysis indicated a higher production rate of PON relative to POP and POC and significant background concentrations of POC. In field samples the concentration of transparent exopolymer particles (TEP) varied around $200 \mu \mathrm{g}$ Xanthan Equiv. $1^{-1}$ and comprised a volume fraction of 2-7 ppm and an abundance of about $10^{5} \mathrm{TEP} \mathrm{ml}^{-1}$. TEP were enriched in aggregates as inferred from volume ratios of TEP to conventional particles. It is suggested, that TEP contribute substantially to the background concentration of POC, while the high production rate of PON is attributed to nitrogen fixation of diazotrophic cyanobacteria.

(C) 2002 Elsevier Science Ltd. All rights reserved.
\end{abstract}

Keywords: biogeochemical elements; organic particles; aggregates; filamentous cyanobacteria; Baltic Sea

\section{Introduction}

The formation of visible particle aggregates (marine snow) and their importance for the vertical transport of elements through the water-column have been acknowledged widely during the last decades (Fowler \& Knauer, 1986; Gardner, 1997). Sinking of aggregates is responsible for pulsed sedimentation of phytoplankton (Alldredge \& Gotschalk, 1989; Riebesell, 1991; Kiørboe et al., 1994) and the occurrence of intense mass fluxes in the deep Ocean (Asper et al., 1992), providing a tight coupling between the pelagic and benthic ecosystems. Through aggregation otherwise floating particles such as positive buoyant cyanobacteria and small picoplankton become entrained in settling aggregates and participate in the vertical particle flux (Grossart, 1996; Waite et al., 2000).

Little is known about the composition of aggregates relative to the bulk fraction of suspended particles and their role for the sequestration of biochemical elements or for the selection of species. Aggregates often

\footnotetext{
${ }^{b}$ Present address: Alfred Wegener Institute for Polar- and Marine Research, D-27515 Bremerhaven, Germany.
}

harbour high abundance of autotrophic and heterotrophic organisms (Alldredge \& Silver, 1988) and can represent microhabitats. High biological activity in aggregates may therefore lead to chemical alteration of the aggregate (Smith et al., 1992; Grossart \& Simon, 1998). Due to differential aggregation, e.g. by different attachment probabilities or adhesion properties (Kiørboe et al., 1990; Crocker \& Passow, 1995), particles can be selectively enriched in aggregates. For example, transparent exopolymer particles (TEP), or mucus particles in general, frequently occur in high concentration in aggregates (Alldredge et al., 1993; Passow \& Alldredge, 1994). In comparison to most conventional particles like plankton and detritus, TEP have a higher C:N ratio (Engel \& Passow, 2001). Thus, an enrichment of TEP in aggregates may be a pathway for the selective removal of organic carbon from surface waters. Since aggregation increases the sinking velocity of particles, differential aggregation may also influence the competition among species (Hansen et al., 1995). However, only a few studies have addressed the enrichment of natural species or groups of organisms in aggregates (Caron et al., 1986; Revelante \& Gilmartin, 1991). 


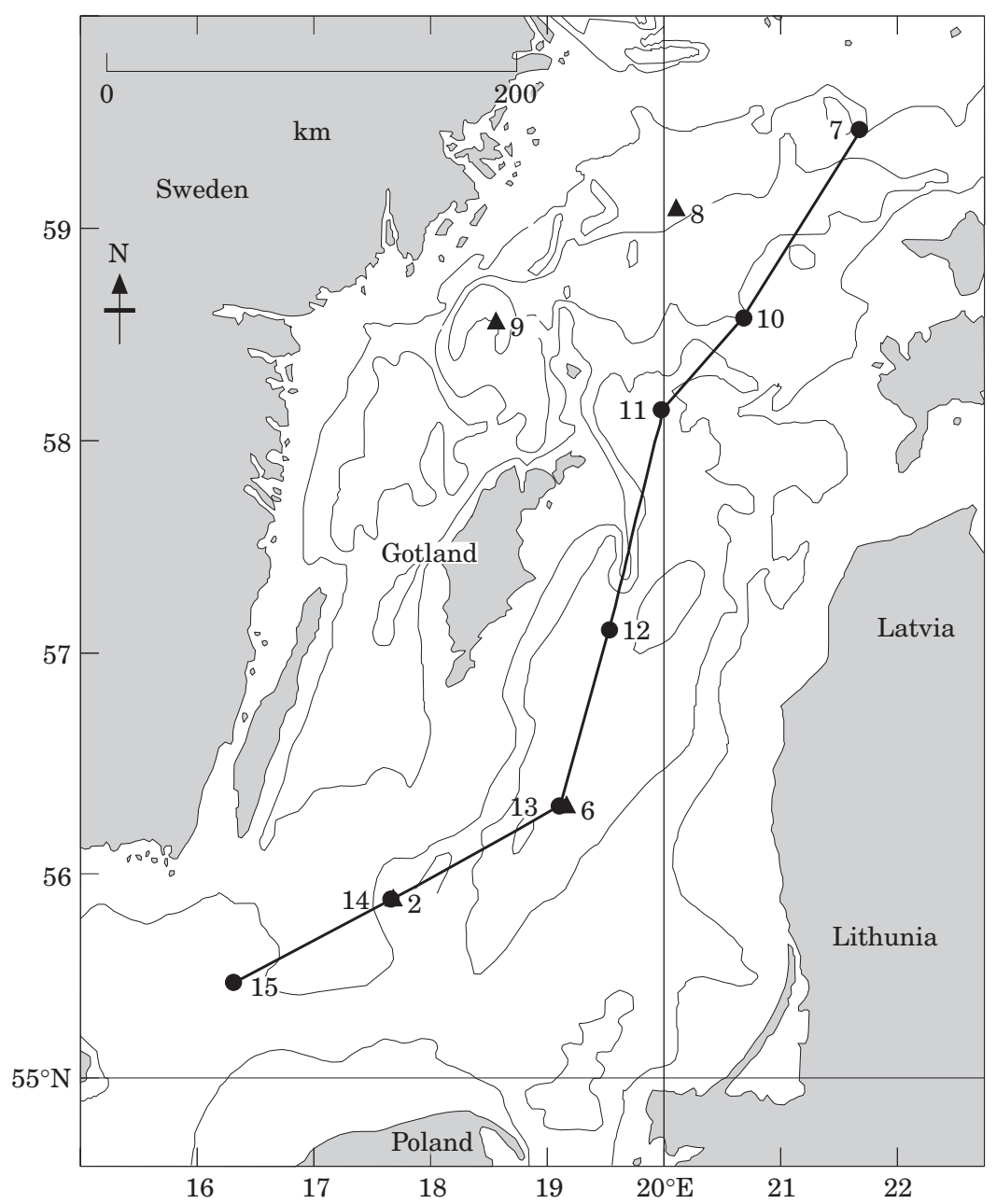

FIgURE 1. Map of the central Baltic Sea (Baltic Proper) with transect (O) and additional stations ( $\mathbf{\Delta})$ sampled during a cruise in June 1999.

In the Baltic Sea nitrogen limits phytoplankton growth after the spring bloom. Filamentous cyanobacteria, which overcome nitrogen limitation by fixing atmospheric $\mathrm{N}_{2}$ are therefore important and abundant primary producers during summer and episodically form extensive surface blooms. Although total export rates are usually small during summer, pulsed sedimentation of the filamentous cyanobacteria Nodularia spp., Anabaena spp. and Aphanizomenon spp. occurred, as measured with sediment traps below $100 \mathrm{~m}$ depth in the Baltic Sea (Gotland Sea) (Wasmund et al., 1999). Aggregates are a major component of sinking material in the stratified Baltic Sea during summer (Lundsgaard et al., 1999; Olli \& Heiskanen, 1999) and may enable the vertical export of the $\mathrm{N}_{2}$-based ' new production' in this system.

The aim of this study was to investigate the potential role of aggregate formation for the sequestration of particulate organic matter in the central Baltic Sea (Baltic Proper) during summer. Since TEP are important agents in aggregate formation, but no data on TEP exist for the central Baltic Sea, special focus was laid on the distribution of TEP and their fraction in aggregates. The question whether aggregates and suspended particles differ with regard to their chemical and biological composition was addressed by comparing suspended particles with aggregates that were produced artificially on a roller table.

\section{Material and methods}

\section{Hydrography and field sampling}

Samples were collected in the Baltic Sea along a transect between $59^{\circ} 25^{\prime} \mathrm{N}, 20^{\circ} 10^{\prime} \mathrm{E}$ and $55^{\circ} 27^{\prime} \mathrm{N}$, $16^{\circ} 20^{\prime} \mathrm{E}$ (Stations $7,10-15$ ) and at four additional 
locations (Stations 2, 6, 8, 9,) in June 1999 (Figure 1). Water was sampled from the surface and at $4,9,14$ and $20 \mathrm{~m}$ depths with 101 Niskin bottles at 5:00 a.m. local time. Salinity and temperature were measured by CTD instruments. Irradiance above sea level was measured all day by a plane 2pi-LICOR quantum sensor.

\section{Aggregation experiments}

At six stations $(2,6,7,9,11,14)$ aggregates were produced on the roller table as described by Shanks and Edmondson (1989). At each station 201 were sampled from the surface and also from 4 and $9 \mathrm{~m}$ depth. Because particle concentration was too low to generate a sufficient quantity of aggregates for the biological and chemical analysis, each of the field samples was enriched in particulate material: First, particles $>0.16 \mu \mathrm{m}$ were concentrated from 201 to approximately 131 by tangential flow filtration (TFF). TFF is a gentle method for the concentration of plankton without significant damage to the cells structure or viability (Petruševski et al., 1995). One litre of filtrate $(<0.16 \mu \mathrm{m})$ was stored at $5{ }^{\circ} \mathrm{C}$ for later resuspension of aggregates. The sample was further enriched with Plankton from 1-2 net catches, collected by Apstein net hauls $(20 \mu \mathrm{m}$ mesh, $16.5 \mathrm{~cm}$ diameter) from $20 \mathrm{~m}$ depth to the surface at a towing speed of $20 \mathrm{~cm} \mathrm{~min}^{-1}$. Each of the enriched samples was split: ten litres were filled into an acrylic cylinder and subjected to rotation on the roller table at $0.5 \mathrm{rpm}$. Two litres were filled into Polycarbonate flasks and served as control for changes in the biological and chemical variables that occurred independent of aggregate formation. The roller table and the controls were kept in darkness for $24 \mathrm{~h}$ at $15^{\circ} \mathrm{C}$. Afterwards, visible aggregates $(>1 \mathrm{~mm})$ were isolated from the cylinders using a $25 \mathrm{ml}$ syringe with a $2 \mathrm{~mm}$ diameter needle. The total volume of the aggregate slurry of each cylinder was measured to the nearest $0.5 \mathrm{ml}$ within the syringe. Aggregate slurries were diluted with $200 \mathrm{ml}$ of appropriate TFF-filtrate and aggregates disintegrated by gentle mixing.

The aggregate slurries consisted of a mixture of aggregates and of surrounding seawater (SSW) collected together with the aggregates, with the volume of SSW being typically much larger than the volume of aggregates. However, particle concentration in aggregates was generally $2-4$ orders of magnitude higher than in the SSW. In order to obtain a conservative estimate of particulate components within the aggregates solely, all concentrations of particulate components in the SSW were subtracted from those in the slurry. The aggregate slurries, the SSW and the controls were analysed separately as described later.

For data presentation the mass content of aggregates was related to the solid aggregate volume $\left(\mathrm{SV}_{\mathrm{AG}}\right)$. The $\mathrm{SV}_{\mathrm{AG}}$ is the sum of the volumes of solid particles within an aggregate that can be detected by the Coulter Counter. In order to compare the results of this study with earlier findings, which relate the mass content of an aggregate to its visible dimensions, we derived the equivalent visible aggregate volume $\left(\mathrm{VV}_{\mathrm{AG}}\right)$. The difference between $\mathrm{SV}_{\mathrm{AG}}$ and $\mathrm{VV}_{\mathrm{AG}}$ is due to the porosity $(\mathrm{P})$, which is the volume fraction of an aggregates occupied by the fluid:

$$
\mathrm{SV}_{\mathrm{AG}} / \mathrm{VV}_{\mathrm{AG}}=1-\mathrm{P}
$$

Alldredge and Gotschalk (1988) determined the porosity of various natural aggregates and showed that (1-P) decreased with the visible diameter of the aggregates $\left(\mathrm{d}_{\mathrm{AG}}\right.$, measured in millimetres) to the power of $-1 \cdot 6$ :

$$
1-\mathrm{P}=0 \cdot 008\left(\mathrm{~d}_{\mathrm{AG}}\right)^{-1 \cdot 6}
$$

Assuming that the aggregate is spherical, equation (1) can be rewritten to:

$$
\mathrm{SV}_{\mathrm{AG}}\left(\mathrm{mm}^{3}\right)=(1 / 750) \pi\left(\mathrm{d}_{\mathrm{AG}}, \mathrm{mm}\right)^{1 \cdot 4}
$$

where the exponent 1.4 is considered as the dimension of fractal scaling (D3). Thus, the visible diameter of an aggregate is related to the solid volume by:

$$
\mathrm{d}_{\mathrm{AG}}(\mathrm{mm})=750 \pi\left(\mathrm{SV}_{\mathrm{AG}}\right)^{(1 / \mathrm{D} 3)}
$$

\section{Biological and chemical analysis}

The particulate organic fractions of carbon (POC), nitrogen (PON) and phosphorus (POP) were determined from 250 to $500 \mathrm{ml}$ of field samples, SSW and controls, and from $50 \mathrm{ml}$ of aggregate slurries filtered onto pre-combusted $\mathrm{GF} / \mathrm{F}$ filters and frozen until analysis at $-18{ }^{\circ} \mathrm{C}$. POC and PON were analysed with a CHN-O-rapid autoanalyser (Hereaus). POP was determined colourimetrically after persulfate oxidation (Koroleff \& Grasshof, 1983). Filters were prepared in duplicates, except for the aggregate slurries. TEP were determined colourimetrically according to Passow and Alldredge (1995) from field samples $(100 \mathrm{ml})$, SSW $(20 \mathrm{ml})$, controls $(20 \mathrm{ml})$ and aggregate slurries $(5 \mathrm{ml})$, each filtered onto $0.4 \mu \mathrm{m}$ Nuclepore filters. Semi-permanent TEP slides were prepared within 1 hour after sampling from field 
samples $(20 \mathrm{ml}), \mathrm{SSW}(10 \mathrm{ml})$, controls $(10 \mathrm{ml})$ and aggregate slurries $(3 \mathrm{ml})$, each filtered onto $0.4 \mu \mathrm{m}$ Nuclepore filters (Passow \& Alldredge, 1994). All TEP filters were prepared in duplicates. TEP slides were transferred to a compound light microscope and screened by a PANASONIC colour video camera on Digital Video with $400 \times$ magnification. About $2 \times 25$ frames per slide were chosen in a cross section and digitized on a Macintosh PPC with an optical resolution of $0 \cdot 17 \mu \mathrm{m}^{2}$ per Pixel. TEP were enumerated and sized semi-automatically by an image analysis program (NIH. Image $6.1 \mathrm{ppc}$., a public domain program developed at the US National Institute of Health). The equivalent spherical diameter (ESD) and the equivalent spherical volume (ESV) of individual TEP were calculated from area measurements assuming the symmetry of a sphere (Mari \& Kiørboe, 1996). Only TEP were counted that did not touch the edge of the frame and contained at least five Pixel, yielding a minimum TEP size of $0.8 \mu \mathrm{m}$. Carbon content of TEP was calculated from colourimetrically determined TEP concentration using the empirical conversion factor of Engel and Passow (2001): $\mathrm{C}_{\mathrm{TEP}}$ $(\mu \mathrm{g})=0.75 \times$ TEP $(\mu \mathrm{g}$ Xanthan Equiv. $)$. Concentration and size distribution of solid particles between 2 and $60 \mu \mathrm{m}$ ESD were determined with the Coulter Counter (Coulter Multisizer II) from replicate $2 \mathrm{ml}$ samples. A dilution with filtered seawater $(<0 \cdot 16 \mu \mathrm{m})$ in order of 1:2 for SSW and controls, and 1:10 to $1: 20$ for aggregate slurries was necessary to keep coincidence of particles at the aperture $<5 \%$. Prior to the Coulter Counter measurements aggregate slurries were again carefully mixed. This was necessary in order to avoid blocking of the orifice during measurement and to enable representative sub-sampling of the aggregate slurry, which is indicated by a small variability between replicate measurements. The content of pigments (chlorophyll and carotenoids) in field samples was determined by means of HPLC (High Performance Liquid Chromatography), using the method of Barlow et al. (1997). Identification of pigments was carried out by comparing their retention times and absorption spectra obtained with a diode array spectrophotometer (WATERS) with those of commercially available pigment standards. Chlorophyll $a$ (chl $a$ ) was purchased from SIGMA, all other pigments from the International Agency for ${ }^{14} \mathrm{C}$ Determination, Denmark. The composition of the phytoplankton communities was calculated using the CHEMTAX program from Mackey et al. (1996), converting the concentrations of marker pigments to equivalents of $\operatorname{chl} a$ with suitable pigment to $\operatorname{chl} a$ ratios. These were obtained from isolations of filamentous cyanobacteria and size-fractionated filtration combined with multiple regression analysis. The abundance of filamentous cyanobacteria and of the dominant species of diatoms and dinoflagellates was also determined by microscopy from Lugol-fixed samples according to Utermöhl (1958). Samples were put under pressure (10 bar) prior to microscopy, which caused implosion of gas vesicles and enabled settlement of otherwise positive buoyant cyanobacteria to the bottom of the Utermöhl chamber. In order to minimize the counting error, at least 50 cells per species or 50 filaments in case of cyanobacteria were counted and at least 500 cells and filaments per sample. The dissolved inorganic compounds of nitrogen (DIN) and phosphorus (DIP) were determined in field samples immediately after sampling with an autoanalyser following the methods of Koroleff and Grasshof (1983).

\section{Results}

\section{Hydrography and nutrient concentrations}

The Baltic Sea is permanently stratified at $\sim 60 \mathrm{~m}$ by a halocline (data not shown), separating the underlying more saline water of $>10$ psu from upper less saline water of $<10 \mathrm{psu}$. The upper layer is well mixed during wintertime, whereas a sharp seasonal thermocline is formed during summer and was located between 10 and $18 \mathrm{~m}$ during the time of observation [Figure 2(a)]. Salinity in the upper layer increased steadily towards the south from $6 \cdot 1$ to $7 \cdot 1$ psu [Figure 2(b)]. Irradiance above sea level ranged between $500 \mu \mathrm{E} \mathrm{m}^{-2} \mathrm{~s}^{-1}$ and $2000 \mu \mathrm{E} \mathrm{m}^{-2} \mathrm{~s}^{-1}$, depending on the cloud coverage. Low but detectable concentrations of phosphate were observed along the transect with surface values between $0.05 \mu \mathrm{mol}^{-1}$ and $0 \cdot 1 \mu \mathrm{moll}^{-1}$, increasing below $10 \mathrm{~m}$ to a maximum of $0.25 \mu \mathrm{mol} \mathrm{l}^{-1}$. Nitrate was below detection limit $\left(0.05 \mu \mathrm{moll}^{-1}\right)$ in almost every sample. Even the combination of the dissolved inorganic nitrogen (DIN) compounds $\mathrm{NO}_{2}^{-}, \mathrm{NO}_{3}^{-}$and $\mathrm{NH}_{4}^{+}$ yielded low concentrations ranging between $0 \cdot 1 \mu \mathrm{mol}^{-1}$ and $0 \cdot 2 \mu \mathrm{mol}^{-1}$ throughout the study area.

\section{Suspended particles along the transect}

The phytoplankton communities along the transect were similar and consisted of small cyanobacteria (mainly Synechococcus spp.), filamentous diazotrophic cyanobacteria (Aphanizomenon 'baltica', Nodularia spumigena and Anabaena spp.), crypto-, chloro-, and prymnesiophyceae, diatoms (mainly Skeletonema costatum and Chaetoceros spp.) and dinoflagellates 

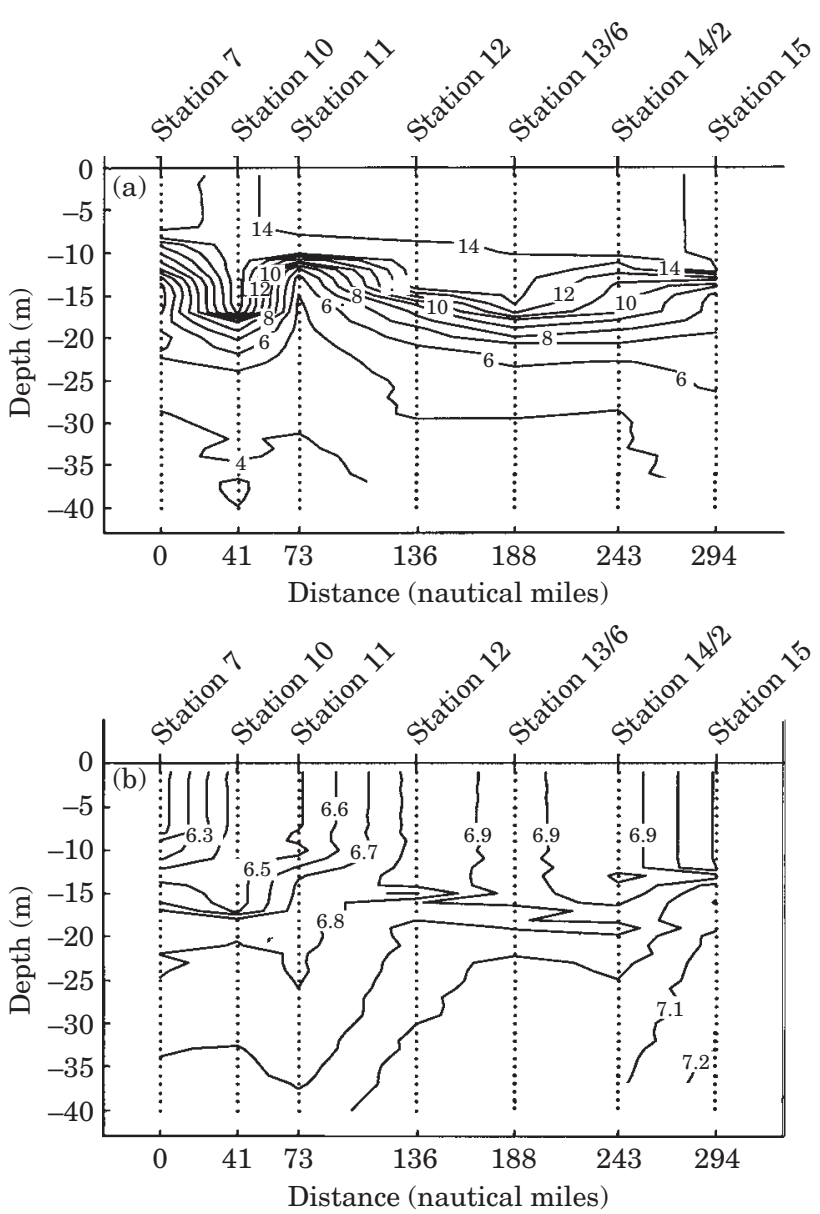

Figure 2. Hydrography of the sampling area. (a) Temperature $\left({ }^{\circ} \mathrm{C}\right)$, (b) Salinity. Vertical lines indicate sampling locations along the transect. The distance indicated is referring to the most northern sampling station 7 .

(mainly Dinophysis norvegica). Chl a varied around a relatively low concentration of $2 \mu \mathrm{g}^{-1}$ and followed no spatial trend along the transect (Figure 3). In terms of relative chl $a$ contribution, cyanobacteria dominated the phytoplankton by adding between 36 and $55 \%$ to total chl $a$, followed by cryptophyceae (up to $25 \%$ ). The remaining chl $a$ was shared between the other groups mentioned above.

Solid particles, detectable with the Coulter Counter (CCP) in the size range $2-60 \mu \mathrm{m} \mathrm{ESD}$, occurred in numerical concentrations of $0.9 \times 10^{3}$ $2 \cdot 0 \times 10^{4} \mathrm{ml}^{-1}$ and comprised a volume fraction of $1-3 \mathrm{ppm}$. An increase in mean number and volume concentration of CCP was observed towards the southern Baltic Sea [Figure 4(a)]. Particle concentrations of TEP $>0.8 \mu \mathrm{m}$ ESD were one order of magnitude higher than CCP concentrations and varied between $6 \times 10^{4}$ and $1.3 \times 10^{5} \mathrm{ml}^{-1}$. The total
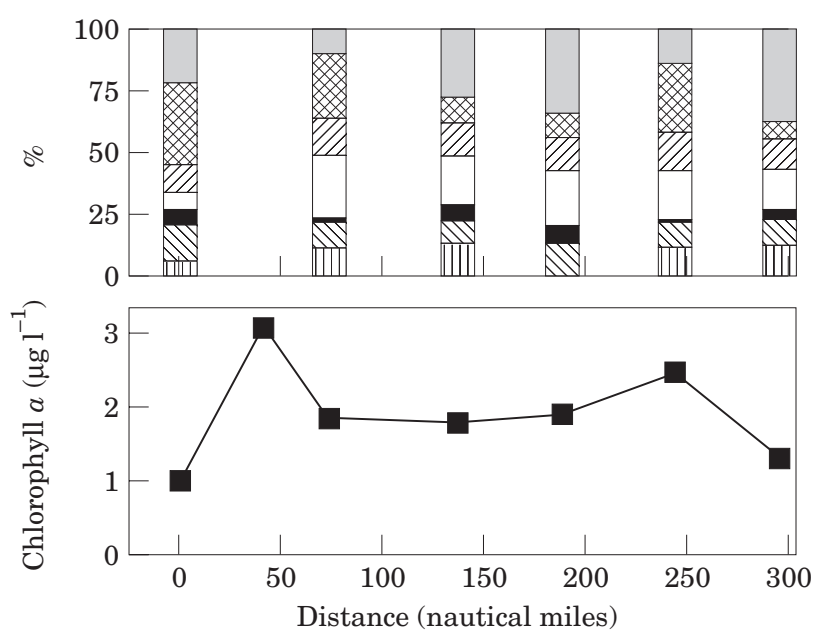

FIGURE 3. Concentration and partitioning of Chlorophyll $a$ within the major phytoplankton groups as determined from accessory pigments by HPLC along the transect. Chlorophyll $a$ concentration were averaged over the upper mixed layer (depth: 0-9 m). [I Dinoflagellates, $\square$ Prymnesiophyceae, $\oslash$ Chlorophyceae, $\square$ Other cyanobacteriae, mainly Synechococcus, $\mathbb{\nabla}$ Diatoms, $\square$ Crytophyceae, Filamentous cyanobacteria.

volume of TEP was about two to three times larger than the total volume of CCP [Figure 4(b)]. In terms of colourimetrically determined TEP, values ranged between 145 and $322 \mu \mathrm{g}$ Xanthan Equiv. $1^{-1}$. Carbon contained in TEP (TEP-C) was on average $13 \mu \mathrm{mol}^{-1}$ and equivalent to roughly $40 \%$ of POC [Figure 4(c)]. Concentrations of particulate organic elements varied around average values of $32 \pm 3 \mu \mathrm{mol} \mathrm{l}^{-1}$ POC, $4 \cdot 4 \pm 0 \cdot 4 \mu \mathrm{mol} \mathrm{l}^{-1}$ PON and $0 \cdot 18 \pm 0.03 \mu \mathrm{mol}^{-1}$ POP and exhibited a similar spatial distribution [Figure 4(c,d)].

Covariations of POC, PON and POP above the thermocline $(0-9 \mathrm{~m})$ were detected from the slopes of linear regressions (Table 1). Slopes were concurrent with the expected Redfield ratio of C:N:P of 106:16:1 (Redfield et al., 1963) in case of $\triangle \mathrm{POC}: \triangle \mathrm{POP}$ $(115 \pm 18)$ but slightly lower for $\triangle \mathrm{POC}: \triangle \mathrm{PON}$ $(5 \cdot 6 \pm 0 \cdot 77)$ and thus higher for $\triangle \mathrm{PON}: \triangle \mathrm{POP}$ $(19 \cdot 4 \pm 2 \cdot 2)$. This indicates a relatively high production rate of PON with respect to POC and POP, and may be explained by the presence of $\mathrm{N}_{2}$-fixing filamentous cyanobacteria, which have an exceptional high nitrogen content (Gabrielson \& Hamel, 1985) and an uptake rate ratio of C:N of about $4 \cdot 4$ (Lindahl, 1987). Significant y-intercepts were observed for regressions of POC $v s$. PON or POP and indicate that a fraction of about $24-35 \%$ of POC was not affected by changes of PON and POP. Consequently, concentration ratios of POC:PON and POC:POP were 

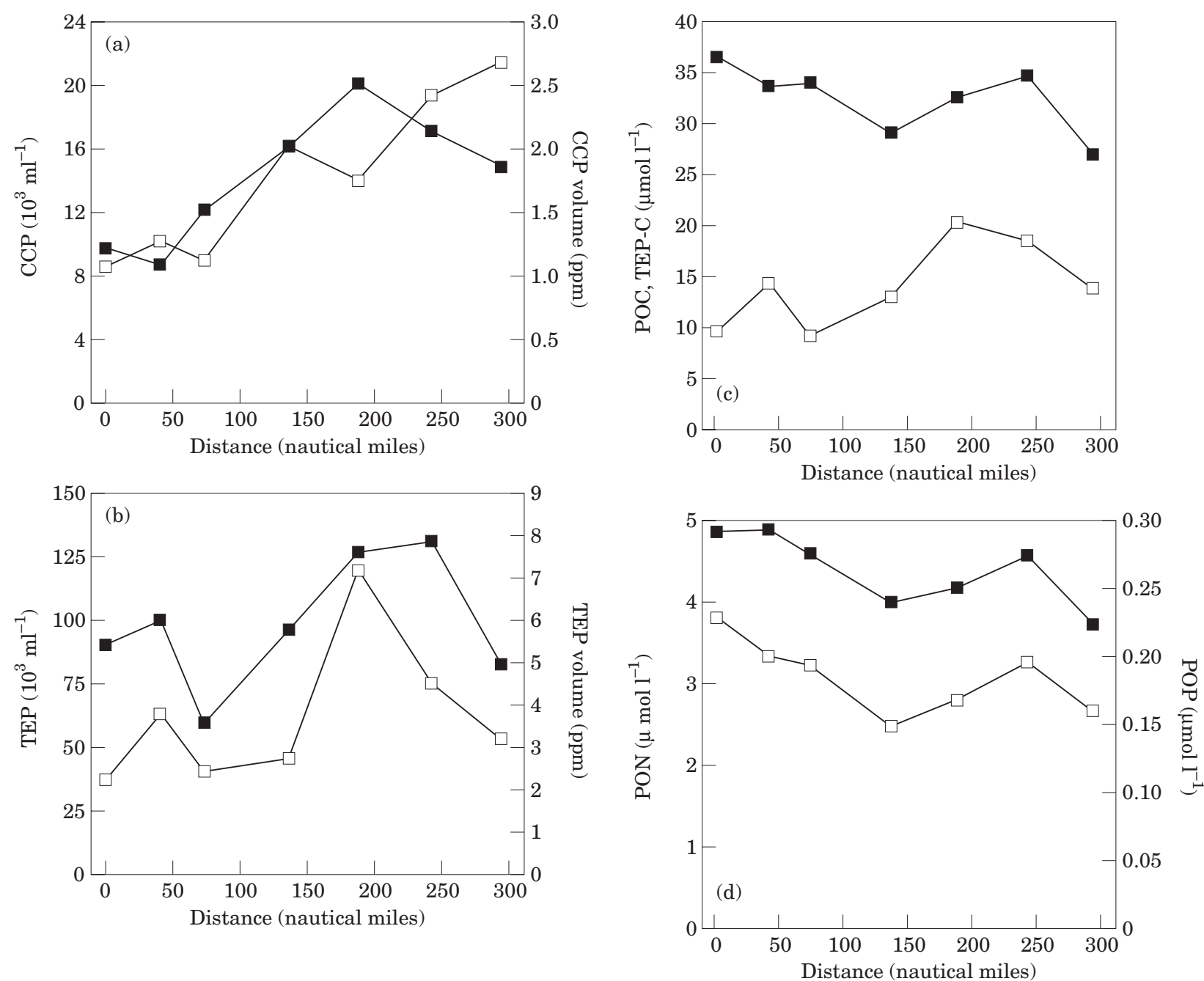

FIgURE 4. Particle composition within the field samples collected along the transect. Values are averages over the upper mixed layer (depth: 0-9 m). Shown are: (a) numerical concentration ( $\square$ ) and volume fraction ( $\square$ ) of CCP (Coulter Counter detectable Particles); (b) numerical concentration ( $\square$ ) and volume fraction ( $\square$ ) of TEP as determined by microscopy; (c) POC ( $\square$ ) and TEP-C as derived from colourimetrically determined TEP ( $\square$ ); (d) PON ( $\square$ ) and POP ( $\square$ ).

significantly higher than slopes of the respective regressions. Linear regression between total nitrogen $(\mathrm{TN})$ defined as $\Sigma\left[\mathrm{PON}, \mathrm{NO}_{3}^{-}, \mathrm{NO}_{2}^{-}, \mathrm{NH}_{4}^{+}\right]$and total phosphorus (TP) defined as $\Sigma\left[\mathrm{POP}, \mathrm{PO}_{4}^{3-}\right]$ yielded a slope not significantly different from the Redfield prediction of 16:1.

\section{Aggregation experiments}

In order to identify changes in the particle composition, due to enrichment by $\mathrm{TFF}$ and addition of net-plankton, control and field samples were compared. Particle enrichment was highly variable between the experiments. In the controls, concentrations of POC, PON and POP were about 2- to 7- fold higher and the volume fractions of TEP and CCP were $1 \cdot 5$ - to 18 -fold larger than in the field. No significant differences between field samples and controls were yet observed concerning the POC:PON: POP ratio and the TEP:CCP volume-ratio (Tables 1 and 4). Abundances of phytoplankton in the controls were 18- to 70-fold higher, but relative abundances of filamentous cyanobacteria, diatoms and dinoflagellates in the controls were within the range of the observed natural variability in the field (Figure 5).

Aggregates that formed during roller table incubations comprised only a minor fraction $(<0.01 \%)$ of the total volume in the cylinders and ranged from $10^{\circ}$ to $10^{2} \mathrm{ml}$ in terms of ' aggregate slurry' volume and from $10^{-3}$ to $10^{-2} \mathrm{ml}$ in terms of total $\mathrm{SV}_{\mathrm{AG}}$. Solid 
TABLE 1. Concentration ratios and regression analysis of particulate organic elements from samples of the upper mixed layer $(0-9 \mathrm{~m})$, collected along a transect at the Baltic Sea in 1999. $\mathrm{TN}^{\star}$ : combined data of DIN $\left(\mathrm{NH}_{4}^{+}, \mathrm{NO}_{2}^{-}, \mathrm{NO}_{3}^{-}\right)$and PON; $\mathrm{TP}^{\star}$ : combined data of $\mathrm{PO}_{4}^{3-}$ and POP; (TEP:CCP): volume ratios of TEP and Coulter Counter detectable particles, ns: not significant

\begin{tabular}{|c|c|c|c|c|c|c|c|}
\hline \multirow[b]{2}{*}{$\begin{array}{l}\text { Variables } \\
(\mathrm{y}, \mathrm{x})\end{array}$} & \multicolumn{2}{|c|}{ Concentration ratio $[\mathrm{y}] /[\mathrm{x}]$} & \multicolumn{5}{|c|}{ Regression analysis } \\
\hline & median & range & $\begin{array}{c}\text { Slopes } \\
\Delta[\mathrm{y}] / \Delta[\mathrm{x}]\end{array}$ & $\mathrm{R}^{2}$ & $P<$ & $\mathrm{y}$-intersect & $\%$ of $y$ \\
\hline POC:PON & $7 \cdot 3$ & $6 \cdot 7-8 \cdot 3$ & $5 \cdot 6 \pm 0 \cdot 77$ & $0 \cdot 78$ & $0 \cdot 001$ & $8 \cdot 2 \pm 3 \cdot 6$ & $24 \pm 11$ \\
\hline POC:POP & 179 & $155-195$ & $115 \pm 18$ & $0 \cdot 73$ & 0.001 & $12 \pm 3 \cdot 5$ & $35 \pm 5$ \\
\hline PON:POP & $23 \cdot 9$ & $21 \cdot 2-27$ & $19 \cdot 4 \pm 2 \cdot 2$ & $0 \cdot 84$ & $0 \cdot 001$ & ns & - \\
\hline $\mathrm{TN}^{\star}: \mathrm{TP}^{\star}$ & $17 \cdot 9$ & $15 \cdot 9-20$ & $16 \cdot 2 \pm 2 \cdot 4$ & $0 \cdot 78$ & $0 \cdot 001$ & ns & - \\
\hline TEP:CCP & $2 \cdot 3$ & $0 \cdot 8-6 \cdot 9$ & ns & - & - & - & - \\
\hline
\end{tabular}

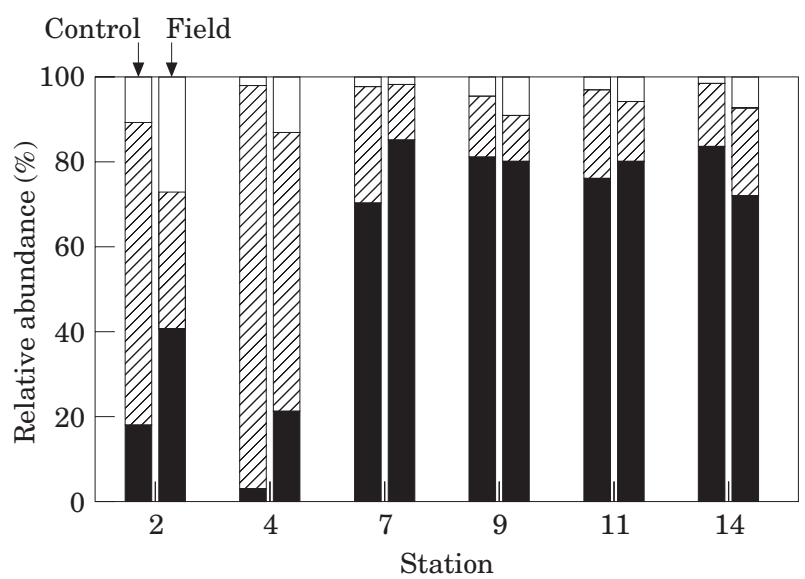

FIGURE 5. Relative abundance of the major phytoplankton groups (filamentous cyanobacteria, diatoms and dinoflagellates) in the enriched control samples and in the respective field samples. Values are averages over samples from the surface, 4 and $9 \mathrm{~m}$ depth for each station. $\square$ Dinoflagellates, $\square$ Diatoms, $\square$ Filamentous cyanobacteria.

particles comprised a volume fraction of $2 \times 10^{2}-$ $3 \times 10^{3} \mathrm{ppm}$ in aggregates, which is $2-3$ orders of magnitude higher than the CCP volume fraction in field samples. The total $\mathrm{SV}_{\mathrm{AG}}$ of each cylinder increased exponentially with the CCP concentration in the control samples $(P<0.001$, data not shown). This indicates that aggregate formation was primarily a function of initial particle concentration.

Overall, aggregates contained a mixed community of filamentous cyanobacteria, dinoflagellates and diatoms, with Aphanizomenon 'baltica', Dinophysis norvegica, Chaetoceros spp. and Skeletonema costatum being the dominant species [Figure 6(a)]. At two stations (2 and 6) aggregates were clearly dominated by dinoflagellates, mainly by Dinophysis norvegica, which comprised $>60 \%$ of cell number. Selective enrichment of one species $\left(\mathrm{E}_{\mathrm{i}}\right)$ was determined by comparing its relative abundances in aggregates and in the control:

$$
E_{i}=\left(n_{i(A G)} / \sum_{i=1}^{N} n_{i(A G)}\right) /\left(n_{i(\text { control })} / \sum_{i=1}^{N} n_{i(\text { contro })}\right)
$$

where the total number of species considered $(\mathrm{N})$ equalled 7. Selective enrichment was most pronounced for Chaetoceros spp., for thecate dinoflagellates (especially on station 2 and 6) and for Nodularia spumigena [Figure 6(b)]. Total phytoplankton abundances in aggregates and controls were not related. However, the abundance of Anabaena spp., Nodularia spumigena and Skeletonema costatum in aggregates increased significantly with the abundances of these species in the controls (Table 2).

Concentrations of particulate organic elements within aggregates ranged from 6.4 to $48 \mathrm{mmol}^{-1}$ POC, from 0.9 to $5.3 \mathrm{mmol}^{-1}$ PON and from 0.02 to $0 \cdot 14 \mathrm{mmol}^{-1}$ POP. TEP concentrations ranged from 8.6 to $57 \mathrm{mg}$ Xanthan Equiv. $1^{-1}$, equivalent to $0 \cdot 5-3 \cdot 6 \mathrm{mmol}^{-1}$ TEP-C. Linear relationships were calculated as a first order approximation for the increase in particulate elements and TEP with the solid volume of aggregates $\left(\mathrm{SV}_{\mathrm{AG}}\right)$ [Figure $7(\mathrm{a}-\mathrm{d})$ ]. For easier comparison of aggregate composition with literature data, the visible volume $\left(\mathrm{VV}_{\mathrm{AG}}\right)$ was calculated from the solid aggregate volume according to equation (4). The fractal scaling used for this calculation was set to $\mathrm{D} 3=1 \cdot 4$, determined for in situ seized aggregates (Alldredge \& Gotschalk, 1988) and to D3 $=1.9$ for aggregates formed on the roller table (Engel \& Schartau, 1999). Due to fractal scaling $\mathrm{VV}_{\mathrm{AG}}$ increases nonlinearly with $\mathrm{SV}_{\mathrm{AG}}$ [equation (2)] and exponential functions were assumed for the regressions of particulate organic elements and TEP vs. $\mathrm{VV}_{\mathrm{AG}}$ (Table 3). The regression equations of POC and $\mathrm{PON}$ vs. $\mathrm{VV}_{\mathrm{AG}}$ derived for $\mathrm{D} 3=1 \cdot 4$ were similar 

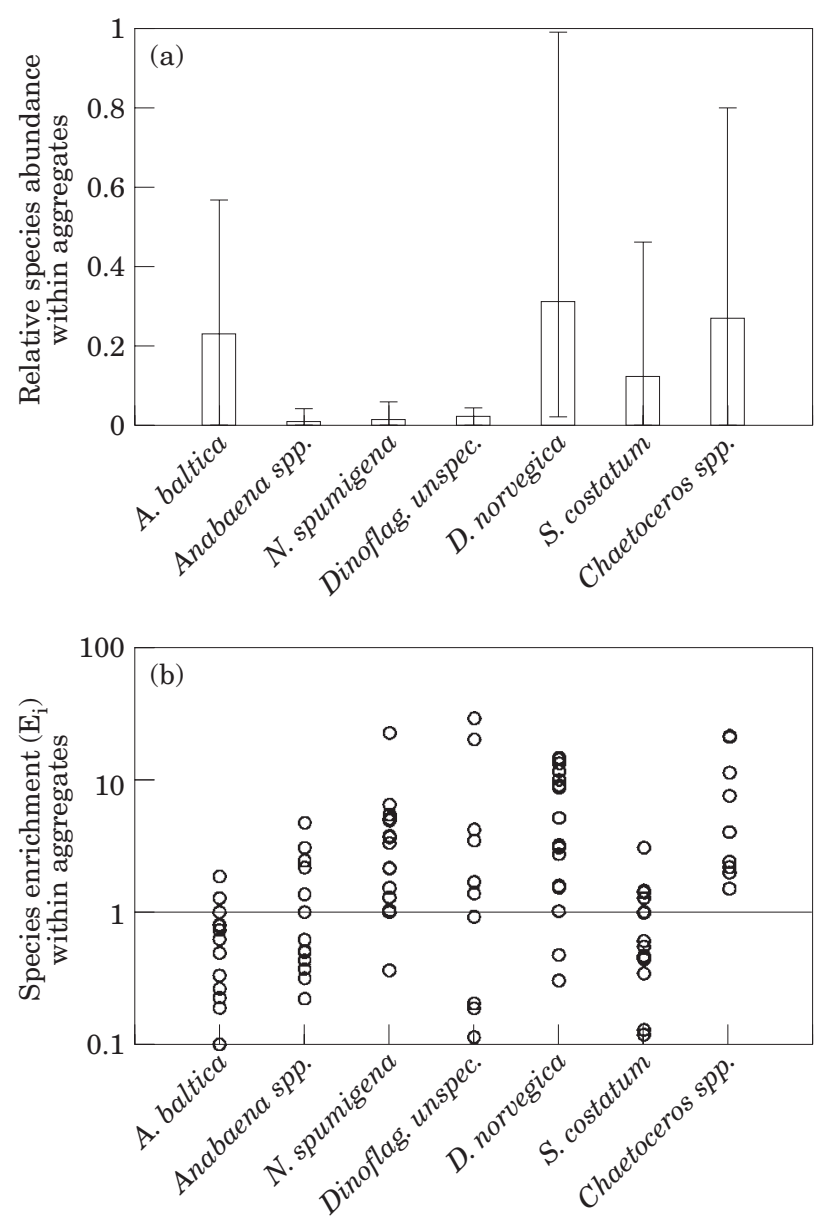

FIGURE 6. Abundance of major phytoplankton species within aggregates formed on the roller table (a) Given are the mean values (open bars) and the range of maximal and minimal abundances (error bars). Selective enrichment $\left(\mathrm{E}_{\mathrm{i}}\right)$ of these species within aggregates (b) was calculated by comparing their relative abundance in the aggregates with their relative abundance in the controls and is shown for each experiment individually $(\bigcirc)$.

to the findings of Alldredge (1990) determined for marine snow isolated in situ, whereas for the higher fractal dimension the relationships were closer to the findings of Ploug and Grossart (2000), who used the roller table approach. This confirms that aggregates, which form on the roller table are more densely packed and have higher fractal dimensions than natural marine snow, as suggested earlier (Lick et al., 1993). It also underlines that the knowledge of the scaling relationship between size and mass of an aggregate is crucial to derive its elemental content from visual measurements.

Linear relationships between POC and PON were determined for aggregates, SSW and controls (Table 4). The slopes ( $\triangle \mathrm{POC}: \triangle \mathrm{PON}$ ) were not significantly different from each other and from the slope that was determined for the field samples. ( $t$-test: $P<0 \cdot 01)$. Again, pronounced y-intersects were observed. The highest absolute and relative y-intersect was determined for aggregates, concomitant with highest concentration ratios of POC:PON. Covariations of POC and PON with POP were less tight and no significant y-intercepts were determined. Thus, no differences between slopes and concentration ratios were observed here. A pronounced deviation from Redfield's prediction was found for aggregates, where POC:POP and PON:POP as well as $\triangle \mathrm{POC}: \triangle \mathrm{POP}$ and $\triangle \mathrm{PON}: \triangle \mathrm{POP}$ were about twice as high as expected and differed significantly from the suspended particles fractions (SSW, controls and field samples; $P<0.001)$. The volume fraction of TEP in aggregates was highly variable, but in general TEP comprised the major part of the particulate volume of aggregates. The volume ratio of TEP and CCP was highest in aggregates, which shows a significant enrichment of TEP in aggregates when compared to the suspended particles fraction (Tables 1 and 4 ).

\section{Discussion}

\section{Preconditions for aggregation in the field}

Particle aggregation depends on the rates of particle collision and particle adhesion. The former is a function of the concentration, size and velocity of particles (McCave, 1984), the latter depends on the physicochemical properties of the particles surface. TEP are of major importance for aggregation processes as they increase bulk particle concentration and bulk stickiness (Alldredge et al., 1993; Logan et al., 1995; Engel, 2000). The formation of aggregates and high production of TEP in situ has mostly been connected with diatom bloom (Alldredge \& Gotschalk, 1989; Riebesell, 1991; Kiørboe et al., 1994), and aggregation in stratified systems with low biomass is expected to be low. During this field study mean TEP concentrations of about $200 \mu \mathrm{g}$ Xanthan Equiv. $1^{-1}$ were measured. Expressed in particle abundance they comprised a volume fraction of 2 to $7 \mathrm{ppm}$ with at a mean number of about $10^{5} \mathrm{ml}^{-1}$. These are the first TEP data reported for the central Baltic Sea. In comparison, Kraus (pers. commun., 1997) determined TEP colourimetrically during the diatom spring bloom at a coastal Baltic Sea location (Kiel Bight), and yielded mean values of about $120 \mu \mathrm{g}$ Xanthan Equiv. $1^{-1}$ while the volume concentration of conventional particles (CCP) ranged between 2 to $6 \mathrm{ppm}$ (Engel, 1998). The ratio of TEP and CCP during the diatom bloom was roughly 2- to 4 -fold lower than during this study and the spring system 
TABLE 2. Correlation between the abundance of one species in aggregates and in controls (a) and between the abundance of one species in aggregates and total phytoplankton abundance in controls (b). ns: not significant. Dinoflagellates other than D. norvegica were not specified

\begin{tabular}{|c|c|c|c|c|}
\hline \multirow[b]{2}{*}{ Species } & \multicolumn{2}{|l|}{ (a) } & \multicolumn{2}{|l|}{ (b) } \\
\hline & $\mathrm{R}^{2}$ species specific & $P<$ & $\mathrm{R}^{2}$ total phytoplankton & $P<$ \\
\hline Aphanizomenon 'baltica' & $0 \cdot 08$ & ns & $0 \cdot 13$ & ns \\
\hline Anabaena spp. & $0 \cdot 75$ & $0 \cdot 005$ & $0 \cdot 05$ & ns \\
\hline Nodularia spumigena & $0 \cdot 52$ & $0 \cdot 07$ & $0 \cdot 00$ & ns \\
\hline Dinoflagellates unspec. & $0 \cdot 01$ & ns & $0 \cdot 17$ & ns \\
\hline Dinophysis norvegica & $0 \cdot 08$ & ns & $0 \cdot 04$ & ns \\
\hline Skeletonema costatum & $0 \cdot 60$ & $0 \cdot 05$ & $0 \cdot 20$ & ns \\
\hline Chaetoceros spp. & $0 \cdot 18$ & ns & $0 \cdot 02$ & ns \\
\hline
\end{tabular}

was clearly dominated by phytoplankton. Thus, the relative importance of TEP in the Baltic Sea seems to be more pronounced during summer than during the diatom spring bloom. This is also supported by the findings of Mari and Burd (1998), who determined the seasonal distribution of TEP in the Kattegat (northwestern Baltic Sea) and observed that TEP concentration during summer was relatively high. There may be several reasons why TEP can be relatively important during summer. First, the removal rate of TEP from the upper water column at times of high CCP, like during diatom blooms, may be higher due to ongoing coagulation and settling of aggregates. Obernosterer and Herndl (1995) showed that exopolymers released by phytoplankton under phosphate limitation are more resistant to bacterial decomposition. In a similar way TEP produced under DIN deficiency in the Baltic Sea during summer may resist bacterial degradation also. On the other hand, TEP production rate may be higher during summer as nutrient limitation enhances TEP production (Kraus, 1997; Corzo et al., 2000).

\section{Particle sequestration during the aggregation experiments}

In this study the potential of aggregate formation in the Baltic Sea was studied by producing artificial aggregates of natural phytoplankton on the roller table. The composition of aggregates that are formed from natural water samples on the roller table is quite similar to those formed in situ (Shanks \& Edmondson, 1989). The roller table has therefore been appreciated as an alternative tool to study aggregates, their formation, composition and chemistry (Crocker \& Passow, 1995; Engel \& Schartau, 1999; Ploug \& Grossart, 2000). Because the samples exposed to rotation on the roller table were enriched in net-plankton, the fraction of phytoplankton cells in the artificial aggre- gates may have been higher than in field aggregates. We therefore compared the phytoplankton composition of aggregates with enriched but not rotated control samples that were incubated under the same temperature and light conditions as the samples on the roller table. Although phytoplankton abundances in the controls were much higher than in the field samples the relative proportions of the major phytoplankton species, the ratios of the particulate organic elements $\mathrm{C}, \mathrm{N}$ and $\mathrm{P}$, and the ratio of TEP to CCP were quite similar. We therefore assume that the relative compositional changes that occurred during aggregate formation reflect natural processes even though the total amount of aggregates yielded during the roller table incubation was higher than in situ.

Aggregation of filamentous cyanobacteria has rarely been studied (Sellner et al., 1988; Grossart, 1996), although floating aggregates have been reported as a final stage of filamentous cyanobacteria blooms. This study showed that the diazotrophic cyanobacteria Aphanizomenon 'baltica', Nodularia spumigena and Anabaena spp. indeed coagulate and form aggregates with pelagic diatoms, such as Chaetoceros spp. and Skeletonema costatum. Different coagulation patterns for individual phytoplankton species were observed. The abundance of Skeletonema costatum, Anabaena spp. and Nodularia spumigena in aggregates depended on their initial concentration, but not on the bulk phytoplankton abundance, which indicates that these species coagulate specifically with themselves. While the relative abundance of Aphanizomenon 'baltica' in aggregates was lower than in the controls, yielding $\mathrm{E}_{\mathrm{i}}$-factors $<1$, Nodularia spumigena was highly enriched in aggregates. The cells of the latter species are covered by a mucus surface coating, which may render them stickier than the filaments of Aphanizomenon 'baltica', which lack a mucus envelope. Coagulation of cyanobacteria with gravitationally 

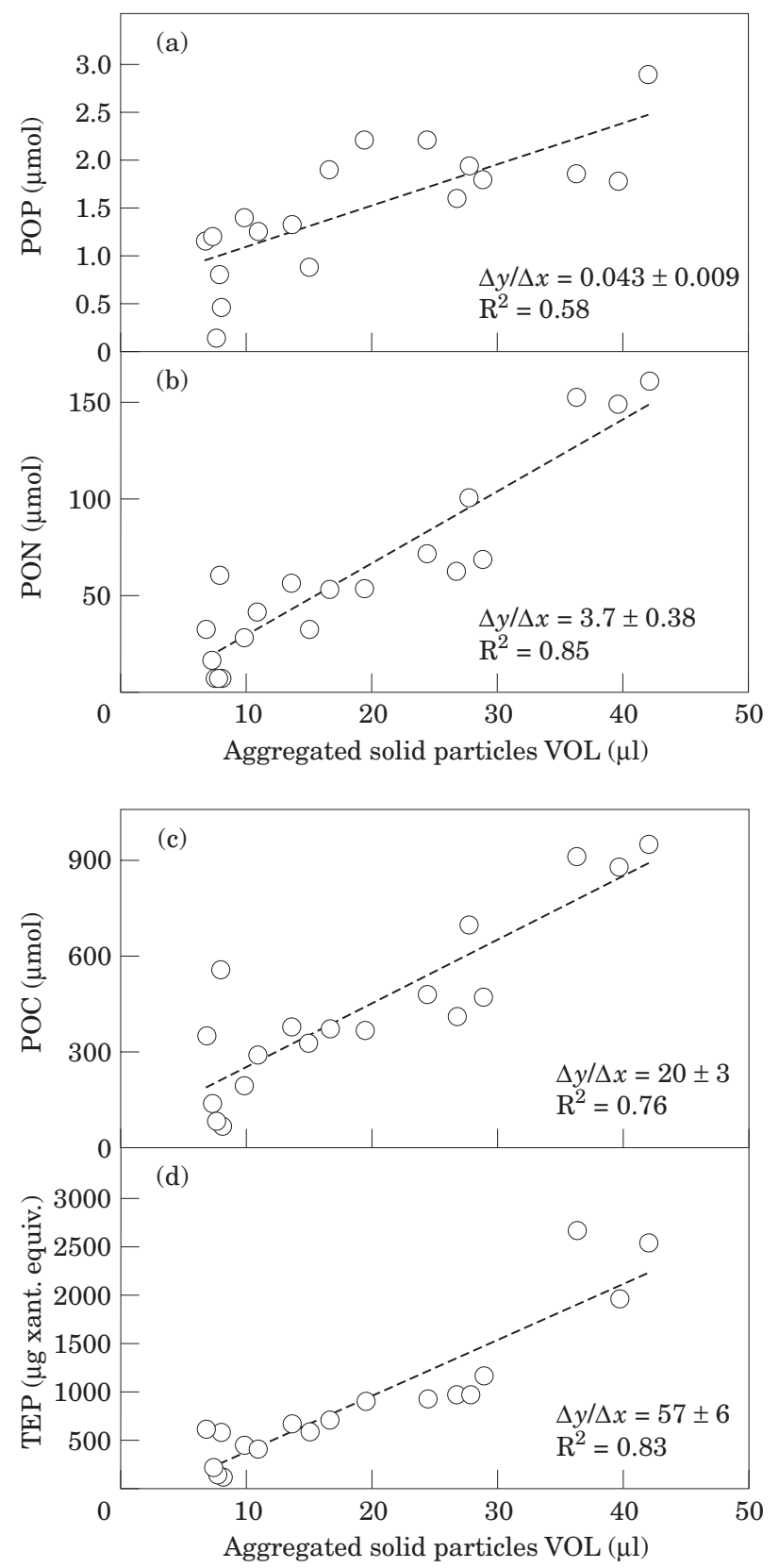

FIGURE 7 (a-d) Increase of particulate organic elements (POC, PON, POP) and TEP with the total volume of solid particles in aggregates.

settling algae will increase the sedimentation rate of cyanobacteria and may be responsible for pulsed sedimentation of filamentous cyanobacteria as observed by Wasmund et al. (1999).

The elemental composition of aggregates differed from the suspended particle fractions in the experiments and in the field. Relatively high background concentrations of carbon in aggregates $(\sim 32 \%$ of total POC) were inferred from regression analysis.
Since this residual POC was independent of PON, it may represent carbon contained in refractory POM and TEP rather than carbon of living biota. TEP form abiotically from dissolved and colloidal exopolymeric carbohydrates (Mopper et al. 1995; Mari, 1999; Passow, 2000) and overlap to a certain, but unknown, degree with the POC pool. The C:N ratio of TEP is significantly higher than the Redfield ratio (Engel \& Passow, 2001). The high ratio of TEP to conventional particles in aggregates may therefore explain the observed carbon enrichment.

During a filamentous cyanobacteria bloom in the Baltic Sea, Sörensen and Sahlsen (1987) observed an increase in the particulate $\mathrm{C}: \mathrm{N}$ ratio below the thermocline. Calculating remineralization ratios Thomas et al. (1999) argued, that material sinking below the thermocline in the Baltic Sea must be enriched in carbon. In both publications the increase in C:N ratios with depth was attributed to the preferential degradation of nitrogen. This study indicates that sedimentation of carbon-enriched aggregates may be another factor responsible for the observed higher $\mathrm{C}: \mathrm{N}$ ratios at depth. A preferential degradation of nitrogen within a short period $(24 \mathrm{~h})$ cannot be supported, neither for aggregated nor for suspended particles, because preferential degradation of PON would lead to an increase in the slope $\triangle \mathrm{POC}: \triangle \mathrm{PON}$, which was not observed. This is consistent with the findings of Grossart and Ploug (2001), who observed that preferential degradation of $\mathrm{PON}$ and increase in POC:PON ratios within detrital diatom aggregates, formed during a similar experiments, did not occur until day five of the incubation. Concentration ratios of POC:POP in the field samples were higher than expected from Redfield's prediction whereas the slope of $\triangle \mathrm{POC}: \triangle \mathrm{POP}$ was close by. This indicates that in fresh material the higher POC:POP ratios were due to enrichment of carbon and not to preferential degradation of the particulate phosphorus. In the aggregation experiments, where the samples were collected after $24 \mathrm{~h}$ of dark incubation, the slopes and the respective concentration ratios of POC:POP were more variable and higher than in the field samples. This was most pronounced for aggregates where a dramatic decrease of phosphorus as inferred from steep slopes ( $\triangle \mathrm{POC}: \triangle \mathrm{POP}$ ) occurred. Degradation of POP is processed by the ectoenzyme alkaline phosphatase, which is released by several bacteria and phytoplankton species. Activities of alkaline phosphatase are higher in aggregates than in the suspended particles fraction (Smith et al. 1992, Grossart \& Simon, 1998) and support a rapid remineralization of POP in aggregates. During this study the scaling relationship between visible volume and mass content 
TABLE 3. Relationships between aggregate mass composition and volume $(n=18) . \mathrm{SV}_{\mathrm{AG}}:$ solid aggregate volume $(\mu \mathrm{l}), \mathrm{VV}$ visible aggregate volume $(\mu \mathrm{l})$, calculated with fractal dimensions (D3) of $1 \cdot 4$ and $1 \cdot 9$, respectively. ns: not significant

\begin{tabular}{|c|c|c|c|c|c|c|c|c|}
\hline & \multicolumn{2}{|c|}{$\operatorname{POP}\left(\mu \mathrm{g} \mu 1^{-1}\right)$} & \multicolumn{2}{|c|}{$\mathrm{PON}\left(\mu \mathrm{g} \mu \mathrm{l}^{-1}\right)$} & \multicolumn{2}{|c|}{ POC $\left(\mu \mathrm{g} \mu 1^{-1}\right)$} & \multicolumn{2}{|c|}{$\operatorname{TEP}\left(\mu \mathrm{g} \mu 1^{-1}\right)$} \\
\hline & $a$ & $b$ & $a$ & $b$ & $a$ & $b$ & $a$ & $b$ \\
\hline $\begin{array}{l}y=a\left(\mathrm{SV}_{\mathrm{AG}}\right)+b \\
y=a\left(\mathrm{VV}_{\mathrm{AG}}\right)^{b}\end{array}$ & $1 \cdot 33$ & 21 & $51 \cdot 8$ & ns & 240 & ns & 57 & ns \\
\hline $\mathrm{D} 3=1 \cdot 4$ & $0 \cdot 13$ & $0 \cdot 33$ & $0 \cdot 07$ & $0 \cdot 54$ & $3 \cdot 3$ & $0 \cdot 42$ & $5 \cdot 3$ & $0 \cdot 40$ \\
\hline D3 $=1 \cdot 9$ & $0 \cdot 15$ & $0 \cdot 47$ & $0 \cdot 08$ & $0 \cdot 76$ & $3 \cdot 7$ & $0 \cdot 59$ & $5 \cdot 9$ & $0 \cdot 56$ \\
\hline$P<$ & $0 \cdot 05$ & - & $0 \cdot 001$ & - & $0 \cdot 005$ & - & $0 \cdot 005$ & - \\
\hline
\end{tabular}

TABLE 4. Concentration ratios and regression analysis of particulate organic elements in aggregates, surrounding seawater (SSW) and controls. (TEP:CCP): volume ratios of TEP and Coulter Counter detectable particles. Number of experiments was 18. ns: not significant

\begin{tabular}{|c|c|c|c|c|c|c|c|c|}
\hline \multirow[b]{2}{*}{ Fraction } & \multirow[b]{2}{*}{$\begin{array}{l}\text { Variables } \\
\quad(\mathrm{y}, \mathrm{x})\end{array}$} & \multicolumn{2}{|c|}{ Concentration ratio $[\mathrm{y}] /[\mathrm{x}]$} & \multicolumn{5}{|c|}{ Regression analysis } \\
\hline & & median & range & $\begin{array}{c}\text { Slopes } \\
\Delta[\mathrm{y}] / \Delta[\mathrm{x}]\end{array}$ & $\mathrm{R}^{2}$ & $P<$ & $\mathrm{y}$-intersect & $\%$ of $y$ \\
\hline \multirow[t]{4}{*}{ SSW } & POC:PON & $6 \cdot 2$ & $5 \cdot 6-7 \cdot 0$ & $5 \cdot 4 \pm 0 \cdot 23$ & 0.97 & $0 \cdot 001$ & $16 \pm 5 \cdot 0$ & $13 \pm 4$ \\
\hline & POC:POP & 135 & $63-173$ & $129 \pm 45$ & $0 \cdot 37$ & $0 \cdot 1$ & ns & - \\
\hline & PON:POP & $21 \cdot 6$ & $9 \cdot 3-28$ & $25 \pm 7 \cdot 7$ & $0 \cdot 41$ & $0 \cdot 05$ & ns & - \\
\hline & TEP:CCP & $2 \cdot 3$ & $0 \cdot 9-11$ & $\mathrm{~ns}$ & - & - & - & - \\
\hline \multirow[t]{4}{*}{ Control } & POC:PON & $6 \cdot 1$ & $5 \cdot 6-8 \cdot 1$ & $5 \cdot 1 \pm 0 \cdot 18$ & $0 \cdot 98$ & $0 \cdot 001$ & $25 \pm 4 \cdot 5$ & $19 \pm 3$ \\
\hline & POC:POP & 143 & $63-169$ & $139 \pm 31$ & 0.57 & $0 \cdot 05$ & ns & - \\
\hline & PON:POP & $21 \cdot 6$ & $8 \cdot 4-29$ & $27 \pm 5 \cdot 8$ & 0.59 & 0.05 & ns & - \\
\hline & TEP:CCP & $2 \cdot 5$ & $0 \cdot 6-11$ & ns & - & - & - & - \\
\hline \multirow[t]{4}{*}{ Aggregates } & POC:PON & $6 \cdot 9$ & $5 \cdot 8-10 \cdot 8$ & $5 \cdot 5 \pm 0 \cdot 3$ & 0.96 & $0 \cdot 001$ & $85 \pm 22$ & $32 \pm 8$ \\
\hline & POC:POP & 270 & $117-679$ & $273 \pm 72$ & $0 \cdot 47$ & 0.05 & $\mathrm{~ns}$ & - \\
\hline & PON:POP & $37 \cdot 7$ & $14 \cdot 2-84$ & $52 \pm 12$ & 0.52 & 0.01 & ns & - \\
\hline & TEP:CCP & 18 & $6 \cdot 5-946$ & ns & - & - & - & - \\
\hline
\end{tabular}

indicated that aggregates, which formed on the roller table, were more densely packed than natural ones. Consequently activities of alkaline phosphatase may have been higher also and the degradation of POP faster than in natural aggregates. However, from an ecological point of view rapid solubilization of POP in aggregates would be advantageous in an $\mathrm{N}_{2}$-fixing system because it retains phosphorus in the upper layer and sustains primary production.

\section{Acknowledgements}

We are grateful to the crew of the Valdivia for their aid in collecting the samples and to Peter Fritsche, Kerstin Nachtigal, Uschi Junghans and Regina Krehl for technical assistance with the chemical analysis. This work was supported by the European Commission within the 'European Land-Ocean Interaction Studies (ELOISE) (Contract: ENV4 CT97 0571). The first author gives special thanks also to the Deutsche Forschungsgemeinschaft (DFG) (Grant EN 416/1-1).

\section{References}

Alldredge, A. L. \& Gotschalk, C. C. 1988 In situ settling behavior of marine snow. Limnology and Oceanography 33, 339-351.

Alldredge, A. L. \& Silver, M. 1988 Characteristics, Dynamics and Significance of Marine Snow. Progress in Oceanography 20, 41-82.

Alldredge, A. L. \& Gotschalk, C. C. 1989 Direct observations of the mass flocculation of diatom blooms: Characteristics, settling velocities and formation of diatom aggregates. Deep-Sea Research 36, 159-171.

Alldredge, A. L., Passow, U. \& Logan, B. E. 1993 The abundance and significance of a class of large, transparent organic particles in the ocean. Deep-Sea Research 40, 1131-1140.

Alldredge, A. 1998 The carbon, nitrogen and mass content of marine snow as function of aggregate size. Deep-Sea Research 45, 529-541.

Asper, V. L., Deuser, W. G., Knauer, G. A. \& Lorenz, S. E. 1992 Rapid coupling of sinking particle fluxes between surface and deep ocean waters. Nature 357, 670-672.

Barlow, R. G., Cummings, D. G. \& Gibb, S. W. 1997 Improved resolution of mono- and divinyl chlorophylls $a$ and $b$ and zeaxanthin and lutein in phytoplankton extracts using reverse phase C-8 HPLC. Marine Ecology Progress Series 161, 303-307.

Caron, D. A., Davis, P. G., Madin, L. P. \& Sieburth, J. McN. 1986 Enrichment of microbial populations in macroaggregates (marine snow) from surface waters of the North Atlantic. Fournal of Marine Research 44, 543-565. 
Corzo, A., Morillo, J. A. \& Rodríguez, S. 2000 Production of transparent exopolymer particles (TEP) in cultures of Chaetoceros calcitrans under nitrogen limitation. Aquatic Marine Ecology 23, 63-72.

Crocker, K. M. \& Passow, U. 1995 Differential aggregation of diatoms. Marine Ecology Progress Series 117, 249-257.

Engel, A. 1998 Bildung, Zusammensetzung und Sinkgeschwindigkeiten mariner Aggregate. Berichte aus dem Institut für Meereskunde Kiel 300.

Engel, A. \& Schartau, M. 1999 Influence of transparent exopolymer particles (TEP) on sinking velocity of Nitzschia closterium aggregates. Marine Ecology Progress Series 182, 69-76.

Engel, A. 2000 The role of transparent exopolymer particles (TEP) in the increase in apparent particles stickiness $(\alpha)$ during the decline of a diatom bloom. Fournal of Plankton Research 22, 485-497.

Engel, A. \& Passow, U. 2001 The carbon and nitrogen content of transparent exopolymer particles (TEP) in relation to their Alcian Blue adsorption. Marine Ecology Progress Series 219, 1-10.

Fowler, S. W. \& Knauer, G. A. 1986 Role of large particles in the transport of elements and organic compounds through the oceanic water column. Progress in Oceanography 16, 147194.

Gabrielson, J. O. \& Hamel, K. S. 1985 Decomposition of the Cyanobacterium Nodularia spumigena. Botanica Marina 28, 2327.

Gardner, W. D. 1997 The flux of particles to the Deep Sea: Methods, Measurements and Mechanisms. Oceanography 10, 116-121.

Grossart, H.-P. 1996 Auftreten, Bildung und mikrobielle Prozesse auf makroskopischen organischen Aggregaten (Lake Snow) und ihre Bedeutung für den Stoffumsatz im Bodensee. Konstanzer Dissertationen, 494, 223 pp.

Grossart, H.-P. \& Simon, M. 1998 Bacterial colonization and microbial decomposition of limnetic organic aggregates (lake snow). Aquatic Marine Ecology 15, 127-140.

Grossart, H.-P. \& Ploug, H. 2001 Microbial degradation of organic carbon and nitrogen on diatom aggregates. Limnology and Oceanography 46, 267-277.

Hansen, J. L. S., Timm, U. \& Kiørboe, T. 1995 Adaptive significances of phytoplankton stickiness with emphasis on the diatom Skeletonema costatum. Marine Biology 123, 667-676.

Kiørboe, T., Andersen, K. P. \& Dam, H. G. 1990). Coagulation efficiency and aggregate formation in marine phytoplankton. Marine Biology 107, 235-245.

Kiørboe, T., Lundsgaard, C., Olesen, M. \& Hansen, J. L. S. 1994 Aggregation and sedimentation processes during a spring phytoplankton bloom: A field experiment to test coagulation theory. Fournal of Marine Research 52, 297-323.

Koroleff, F. \& Grasshof, K. 1983 Determination of nutrients. In Methods of seawater analyses, 2 (Grasshof, K., Erhardt, M. \& Kremling, K., eds). Verlag Chemie, pp. 125-188.

Kraus, M. 1997 Zur Bildung von TEP (transparent exopolymer particles) in der Kieler Bucht. MSc thesis, University of Kiel.

Lick, W., Huang, H. \& Jepsen, R. 1993 Flocculation of fine-grained sediments due to differential settling. Fournal of Geophysical Research 98, 10279-10288.

Lindahl, G. 1987 Nitrogen fixation, primary production and phosphatase activity during a Nodularia bloom. In Nitrogen dynamics of a cyanobacteria bloom in the Baltic Sea: new versus regenerated production (Sörensson, F. \& Sahlsten, E., eds). Marine Ecology Progress Series 37, 277-284.

Logan, B. E., Passow, U., Alldredge, A. L., Grossart, H.-P. \& Simon, M. 1995 Rapid formation and sedimentation of large aggregates is predictable from coagulation rates (half-lives) of transparent exopolymer particles (TEP). Deep-Sea Research 42, 203-214.

Lundsgaard, C., Olesen, M., Reigstad, M. \& Olli, K. 1999 Sources of settling material: aggregation and zooplankton mediated fluxes in the Gulf of Riga. Fournal of Marine Systems 23, 197210.

Mackey, M. D., Mackey, D. J., Higgins, H. W. \& Wright, S. W. 1996 CHEMTAX - a program for estimating class abundances from chemical markers: application to HPLC measurements of phytoplankton. Marine Ecology Progress Series 144, 265-283.

Mari, X. \& Kiørboe, T. 1996 Abundance, size distribution and bacterial colonization of transparent exopolymeric particles (TEP) during spring in the Kattegat. Fournal of Plankton Research 18, 969-986.

Mari, X. \& Burd, A. 1998 Seasonal size spectra of transparent exopolymeric particles (TEP) in a coastal sea and comparison with those predicted using coagulation theory. Marine Ecology Progress Series 163, 63-76.

Mari, X. 1999 Carbon content and C:N ratio of transparent exopolymer particles (TEP) produced by bubbling of exudates of diatoms. Marine Ecology Progress Series 33, 59-71.

McCave, I. N. 1984 Size spectra and aggregation of suspended particles in the deep ocean. Deep-Sea Research 31, 329-352.

Mopper, K., Zhou, J., Ramana, K. S., Passow, U., Dam, H. G., Drapeau, D. T. 1995 The role of surface-active carbohydrates in the flocculation of a diatom bloom in a mesocosm. Deep-Sea Research II 42, 47-73.

Obernosterer, I. \& Herndl, G. J. 1995 Phytoplankton extracellular release and bacterial growth: dependence on inorganic N.P ratio. Marine Ecology Progress Series 116, 247-257.

Olli, K. \& Heiskanen, A.-S. 1999 Seasonal stages of phytoplankton community structure and sinking loss in the Gulf of Riga. Fournal of Marine Systems 23, 165-184.

Passow, U. \& Alldredge, A. L. 1994 Distribution, size and bacterial colonization of transparent exopolymer particles (TEP) in the ocean. Marine Ecology Progress Series 113, 185-198.

Passow, U. \& Alldredge, A. L. 1995 A dye binding assay for the spectrophotometric measurement of transparent exopolymer particles (TEP) in the ocean. Limnology and Oceanography 40, 1326-1335.

Passow, U. 2000 Formation of transparent exopolymer particles, TEP, from dissolved precursor material. Marine Ecology Progress Series 192, 1-11.

Petruševski, B., Bolier, G., Van Breemen, A. N. \& Alaerts, G. J. 1995 Tangential flow filtration: A method to concentrate freshwater algae. Water Research 29, 1419-1424.

Ploug, H. \& Grossart, H.-P. 2000 Bacterial growth and grazing on diatom aggregates: Respiratory carbon turnover as a function of aggregate size and sinking velocity. Limnology and Oceanography 45, 1467-1475.

Redfield, A. C., Ketchum, B. M. \& Richards, F. A. 1963 The influence of organism on the composition of seawater. In The Sea (Hill, M. N., ed.). Wiley, pp. 26-77.

Riebesell, U. 1991 Particle aggregation during a diatom bloom. II Biological aspects. Marine Ecology Progress Series 69, 281-291.

Revelante, N. \& Gilmartin, M. 1991 The phytoplankton composition and population enrichment in gelatinous ' macroaggregates' in the northern Adriatic during the summer of 1989. Fournal of Experimental Marine Biology and Ecology 146, 217-233.

Sellner, K. G., Lacouture, R. V. \& Parrish, C. R. 1988 Effects of increasing salinity on a cyanobacterial bloom in the Potomac River estuary. Fournal of Plankton Research 10, 49-61.

Shanks, A. L. \& Edmondson, E. W. 1989 Laboratory-made marine snow: biological model of the real thing. Marine Biology 101, 463-470.

Smith, D. C., Simon, M., Alldredge, A. L. \& Azam, F. 1992 Intense hydrolytic enzyme activity on marine aggregates and implications for rapid particle dissolution. Nature 359, 139-141.

Sörensson, F. \& Sahlsten, E. 1987 Nitrogen dynamics of a cyanobacteria bloom in the Baltic Sea: new versus regenerated production. Marine Ecology Progress Series 37, 277-284.

Thomas, H., Ittekot, V., Osterroth, C. \& Schneider, B. 1999 Preferential recycling of nutrients - the ocean's way to increase new production and to pass nutrient limitation? Limnology and Oceanography 44, 1999-2004. 
Utermöhl, H. 1958 Zur Vervollkommnung der quantitativen Phytoplankton-Methodik. Int. Ver. Theor. Angew. Limnol. Mitt. 9, $1-38$.

Waite, A. M., Safi, K. A., Hall, J. A. \& Nodder, S. D. 2000 Mass sedimentation of picoplankton embedded in organic aggregates. Limnology and Oceanography 45 (1), 87-97.
Wasmund, N., Alheit, J., Pollehne, F., Siegel, H. \& Zettler, M. L. 1999 Der biologische Zustand der Ostsee im Jahre 1998 auf der Basis von Phytoplankton-, Zooplankton- und Zoobenthosuntersuchungen. Meereswissenschaftliche Berichte aus dem Institut für Ostseeforschung 37, 75 pp. 